\section{Anonymous Bounty}

SIR,--Under the heading "Anonymous Bounty" (Nature, 225,$783 ; 1970$ ) you refer to tho endowment fund of $£ 250,000$ given to the World Wildlifo Fund, with the comment that the donor. "gave no stipulation as to how the monoy should be spent". I would like to stress that the $£ 250,000$ itself cannot be spent at all--only the much more modest income from it.

Nevertholess the high priority projects for which we hope to find funds in 1970 include the following: the work of the Legislation Commission of the International Union for Conservation of Nature and Natural Resources in preparing an "International Convention on Export, Import and Transit of Certain Species of Wild Animals and Plants", the work of the Intcrnational Wildfowl Research Bureau in proparing an "International Wetland Convention" designed to preserve marshes and their plant and animal communities; the work of the Advisory Committee on Oil Pollution, and of the International Council for Bird Proservation towards prevention of oil pollution; the work of the Charles Darwin Foundation for the Galupagos Islands ' $n$ averting the extinction of the endemic flora and fauna, so much of which is of spectacular interest; the work of the Survival Service Commission of IUCN for threatened species, especially at the momont for apes, big cats, polar bears, wild cattle, rhinoceroses, sirenians, whalcs, the monkey-cating eagle, the white-winged wood duck, the Hawaiian goose, the cranes and the bustards, marine turtiles, crocodiles and threatened plant species; a major conservation programme for Madagascar's unique fauna and flora; support for the 4,800 square miles of Manu National Park, an unspoiled valley in the Andes of Peru; support for the Cayapas Reserve in Ecuador; and the Awash National Park in Ethiopia; and the Shimba Hills in Kenya; the acquisition of a reserve area in the Papuan Gulf, New Guinea; the acquisition of marshlands at Marchauen in Austria; a concerted effort to save the tamaraw (the Philippine wild ox) and the kouprey (the Cambodian wild $\mathrm{ox}$ ) from extinetion; a management plan and survey of the Nile crocodile in Ethiopia and the marine turtles on the SE coast of Africa; a conservation programme for the great Indian bustard; a motor launch and equipment for the research station at Aldabra; a continuing scientific prosence and programme for the Udjung Kulon Reservo in Java (where the last 25-28 Javan rhinos survive), and a comparable programme for the mountain gorilla in Rwanda and the Congo; support for the Marine National Park of Kenya; and for a bird observatory at Lake Nakuru, Kenya. Financial help for conservation is urgently needed in Indoncsia, Sudan, India and Pakistan, and particularly for the Collego of African Wildlife Management at Mweka, Tanzania, and the School for the Training of Wildlife Specialists at Garoua, Cameroon. In Israel support is needed for a very large and imaginative programme of Field Study Centres for Conservation. Immediate help is also needed to save a number of oceanie islands from total dogradation.

In the UK there are projects for land aequisition and reserve establishment in the following places: on the Ouse Washes in Norfolk and Cambridgeshire; at Martin Mere, Lancashire; on the Glen Washes, Lincolnshire; at Caerlaverock on the Solway Firth; at Predannack, Cornwall; at North Hill Tor, Glamorgan; near Hickling Broad, Norfolk; at Great Merrible Wood, Fox Covert and Poultney Wood in Leicestershire; at Colne Point, Essex; at Bix Bottom, Oxfordshire; and at Lower Whetmoor Woods, Gloucestershire. There is a project for the study and conservation of the large blue buttorfly-probably Britain's most prominent spceies threatened with world extinction. Educational projects are required for Wicken Fen, Strangford Lough, and Fair Isle; and there is a rescarch project on the disappearing sand lizard. There are somo 16 nature resorve areas in Scotland which neod support and this will be done through the Scottish Wildlife Trust.
I hope I may have made the point that a good doal more money is needed. Some of theso projects may not soem very important in isolation, but if all can be undertaken they will add up to a significant amount of solid conservation achievement.

Yours faithfully,

Slimbridge,

Petell Scott

Gloucestershire.

\section{University News}

Dr T. F. Slater, University College Hospital Medical School, has been appointed to the newly established chair of biochemistry at Brunel University.

Tho title of Professor of Chemical Pathology has been conferred on Dr F. V. Flynn in respect of his post at University Collogo Hospital Medieal School, Londor, and that of Reader in Mechanical Engineering on Dr R. M. Davies in respect of his post at University College London.

\section{Announcements}

Five new members have been elceted to the board of trustees of the Salk Institute: Dr A. F. Brimmer, US Federal Reserve Board; Dr A. Hammer, Occidental Petroleum Corporation; Masaru Ibuka, Sony Corporation; Dr Seiji Kaya, University of Tokyo; Dr Norman H. Topping, University of Southern California.

The fifth Founders medal of the US National Academy of Engineering has been awarded to Professor Charles Stark Draper of MIT.

The Council of the Royal Society has awarded the John Murray travelling studentship for 1970 to Professor F. Oldfield, New University of Ulster, to enable him to carry out research on recent productivity changes in eutrophic lakes.

Finratum. In tho article "Growing Pains in British Universities" (Nature, 225, 407; 1970), the sccond and third sentences in the third paragraph should read: "Fig. 1 shows that between 1959 and 1965, expenditure increased at an average annual rate of about $18 \mathrm{per}$ cent, while student numbers rose by about 7 per cent a year. But after 1965, when Colleges of Advanced Technology received university status, the increase in expenditure seems to have becn reduced to about 9 per cent a year, whilo student numbers continued to rise at an average yearly ratc of about 8 per cent".

Frratum. In the article "Stimulation by Cyclic AMP of Intrinsic Protein Kinase Activity in Ox Brain Membrane Preparations", by M. Weller and R. Rodnight (Nature, 225, 187; 1970), the ordinate of Fig. 1 should read: nmoles $\left[{ }^{32} \mathrm{P}\right]$-phosphorylserine/mg protein.

\section{International Meetings}

September 27--October 1, Congress of the International Society for Fat Research, Chicago (Dr F. Bradley, 136 Sharps Lane, Ruislip, Middlesex).

September 27-October 2, Second Harden Conference, Ashford, Kent (Dr A. P. Mathias, Department of Biochemistry, University College, Gower Street, London WC1).

September 28-October 2, Gas Chromatography, Dublin (The Conference Secretary, Institute of Petroleum, 61 New Cavendish Street, London WIM 2AR). 